\title{
PROPERTIES OF SELF COMPACTING CONCRETE USING POLYVINYL ALCOHOL FIBERS
}

\author{
G. Vinod kumar $^{1} \&$ Md. Naveedul Haq ${ }^{2}$
}

\begin{abstract}
The aim of present study is to evaluate the properties of Self compacting concrete using polyvinyl alcohol fibers with partial replacement of cement with fly ash. The fly ash used in this study is of class-C type. For this study M30 grade Self compacting concrete is prepared as per the EFNARC guidelines and workability, durability and mechanical properties like compressive strength, split tensile strength and flexural strength were evaluated. Polyvinyl alcohol fibers are added at a constant rate of $0.125 \%$ by volume of concrete, Cement is replaced with Fly ash for replacement levels of $0 \%, 10 \%, 20 \%, 30 \%$, 40\% and workability, durability properties and mechanical properties like compressive strength, split tensile strength and flexural strength were evaluated for the age of 7 days, 28 days,56 days. Stress-strain relation of concrete with $0 \%$ and $30 \%$ Fly ash is observed and Modulus of Elasticity is calculated. The water- cement ratio adopted is 0.4.

Keywords: Self compacting concrete, fly ash, Polyvinyl alcohol fibers, EFNARC guidelines
\end{abstract}

\section{INTRODUCTION}

Self compacting concrete is a workable type of concrete used in concrete structures with no compaction. Self compacting concrete requires no vibration at the site. This type of concrete development should hold a firm equality between evenness and durability. This was developed by Japanese researchers in 1988 to have good strength characteristics regarding fresh and hardened states of concrete. Also, consolidation was greatly influenced by the specification of materials and the replacement proportions. Hence, it is quiet necessary to improve the mix design properties of Self compacting concrete. The design is chosen to accept all the characteristics of concrete both in workable and durable states. There is no specific mix design procedure for self compacting concrete. As per EFNARC guidelines one of the major differences between ordinary concrete and self compacting concrete is inculcating mineral admixture. Thus, many studies has generated on the study of inculcating additives with decreasing binder content. Since, cement is the major costliest part of concrete, usage of mineral admixture reduces the cement content and improves the economy. Additionally, strength development additives can exhibit good particle packing and reduces the pore structure of concrete. Hence, it results in the increase of durability properties of concrete. Industrial wastes such as fly ash were used as additives in the self compacting concrete. Therefore workability of concrete is increased. Polyvinyl alcohol fibers were used to improve the strength and also to resist the failure in flexure, cracking.

\section{MATERIALS AND THEIR PROPERTIES}

\subsection{Cement:}

The type of cement used in this investigation is Ordinary Portland cement of 43 grade having Specific gravity of 3.12, Fineness of 4.8\%, Consistency of 29\%, Initil and Final setting time of 90 and 195 min respectively.

\subsection{Fine aggregate:}

All sand conforming to IS:383-1970 can be used for self compacting concrete. The sand obtained for the investigation is from nearby river course and confining to Zone-III having Specific gravity 2.7, Fineness modulus of 2.55, Bulk density(compacted) of $16.7 \mathrm{KN} / \mathrm{m}^{3}$.

\subsection{Coarse aggregate:}

The coarse aggregate used in this investigation are obtained from local crushing unit. The maximum size of aggregate used in this investigation is $10 \mathrm{~mm}$. The Specific gravity is 2.75 , Fineness modulus is 7.26 , Bulk density(compacted) is $16.1 \mathrm{KN} / \mathrm{m}^{3}$.

\subsection{Mineral additive:}

Fly ash of class-C type is used in this investigation which is replaced for cement. Fly ash is a by product formed by burning pulverized coal in electric power generating plants. During combustion, mineral impurities in the coal (clay, feldspar, quartz, and shale) fuse in suspension and float out of the combustion chamber with the exhaust gases.

\footnotetext{
${ }^{1}$ M Tech, Structural Engineering, Dept of Civil Engineering, JNTU Kakinada

${ }^{2}$ Assistant Executive Engineer, Irrigation Dept, Pitapuram
} 
2.5 Polyvinyl alcohol fibers (PVA):

Polyvinyl alcohol fiber (PVA) is an ideal environment-friendly cement reinforced material, which possesses alkali and weather resistance due to its unique molecular structure, taking on good affinity to cement, effectively prevent and suppress the crack formation and development, improve bending strength, impact strength and crack strength, improve permeability, impact and seismic resistance of concrete.

\subsection{Chemical admixture:}

Conplast SP430 is used for this investigation. It is used for obtaining high degree workability and its retention are required, where delays in transportation or placing are likely or when high ambient temperatures cause rapid slump loss. It facilitates production of high quality concrete. Conplast SP430 complies with IS:9103:1999 and BS:5075 Part 3 and ASTM-C-494 Type ' $\mathrm{F}$ ' as a high range water reducing admixture and Type $\mathrm{G}$ at high dosage. Specific gravity is $1.2-1.22$ at $300^{0} \mathrm{C}$.

\subsection{Viscosity Modifying Agent (V.M.A):}

Auromix 400 is used in this investigation. Auromix 400 is a unique combination of the latest generation super plasticizers, based on a polycarboxylic ether polymer with long lateral chains. This greatly improves cement dispersion. Auromix 400 combines the properties of water reduction and workability retention. It allows the production of high performance concrete or concrete with high workability.

\section{MIX DESIGN}

3.1 Mix design:

There is no standard method to determine the mix proportions for self compacting concrete. However, many different proportion limits have been listed in EFNARC specifications. In this investigation, initially the mix design is carried out as per IS 10262-2009 and latter the quantities are determined by verifying the guidelines of EFNARC specifications.

Design:

- $\quad$ Grade of concrete- M30

- Cement grade - 43 grade

- Maximum size of aggregate $-10 \mathrm{~mm}$

- Specific gravity of fine aggregate -2.7

- Specific gravity of coarse aggregate -2.75

- Specific gravity of cement -3.12

- Specific gravity of fly ash -2.2

- Sand : Zone III

Step-1: Target mean strength (f ck)

$$
\mathrm{f}^{1}=\mathrm{f}+1.65 * \mathrm{~s}
$$

$\mathrm{ck} \quad \mathrm{ck}$

s- Standard deviation from Table-1 IS 10262-2009 ( $\mathrm{s}=5$ )

$\mathrm{f}^{1}=38.25 \mathrm{MPa}$

ck

Step-2: Selection of water-cement ratio W/C $=0.4$ (after many trails)

Step-3: Maximum water content

From table-2 IS 10262-2009 Water content $=208$ lit

Step-4 : Required water content is $200 \mathrm{lit} / \mathrm{m}^{3}$

Step $-5:$ Cement content $=500 \mathrm{~kg} / \mathrm{m}^{3}$

Step-6: Air entrapped-1\%

Step-7: From table-3 IS 10262-2009 Volume of coarse aggregate $=0.46$ Volume of fine aggregate $=0.54$

Step- $8:$ Volume of material $=$
Specific gravity of material

Volume of cement $=0.159 \mathrm{~m}^{3}$ Volume of water $=0.2 \mathrm{~m}^{3}$

Volume of total aggregate $(\mathrm{e})=0.662 \mathrm{~m}^{3}$

Step-9: Mass of fine aggregate $=\mathrm{e} x$ Volume of fine aggregate $\mathrm{x}$ Specific gravity of

Fine aggregate

Mass of fine aggregate $=873.2 \mathrm{~kg} / \mathrm{m}^{3}$

Mass of coarse aggregate $=\mathrm{e} x$ Volume of fine aggregate $\mathrm{x}$ Specific gravity of

Coarse aggregate

Mass of coarse aggregate $=821.1 \mathrm{~kg} / \mathrm{m}^{3}$ 
SP dosage $-0.7 \%$ of powder content VMA dosage $-0.5 \%$ of powder content

Therefore, the Mix proportion obtained is

Cement: F.A : C.A = 1: 1.746:1.6422

\subsection{Proportions for mix:}

\begin{tabular}{|l|l|l|l|l|l|}
\hline Material & Control & $\begin{array}{l}10 \% \text { Fly ash } \\
\text { replacement }\end{array}$ & $\begin{array}{l}20 \% \text { Fly ash } \\
\text { replacement }\end{array}$ & $\begin{array}{l}30 \% \text { Fly ash } \\
\text { replacement }\end{array}$ & $\begin{array}{l}40 \% \text { Fly ash } \\
\text { replacement }\end{array}$ \\
\hline Cement & 500 & 450 & 400 & 350 & 300 \\
\hline Fly ash(kg) & - & 50 & 100 & 150 & 200 \\
\hline Water(1) & 200 & 200 & 200 & 200 & 200 \\
\hline FA(kg) & 873.2 & 873.2 & 873.2 & 873.2 & 873.2 \\
\hline CA(kg) & 821.1 & 821.1 & 821.1 & 821.1 & 821.1 \\
\hline SP(l) & 3.5 & 3.5 & 3.5 & 3.5 & 3.5 \\
\hline VMA(l) & 2.5 & 2.5 & 2.5 & 2.5 & 2.5 \\
\hline $\begin{array}{l}\text { PVA fibers } \\
(\%)\end{array}$ & 0.125 & 0.125 & 0.125 & 0.125 & 0.125 \\
\hline
\end{tabular}

\subsection{Mix notations:}

1. FA-0 : Nominal SCC mix with $0.125 \%$ PVA fibers

2. FA-10 : $10 \%$ Fly ash and $0.125 \%$ PVA fibers

3. FA-20 : $20 \%$ Fly ash and $0.125 \%$ PVA fibers

4. FA- $30: 30 \%$ Fly ash and $0.125 \%$ PVA fibers

5. FA- $40: 40 \%$ Fly ash and $0.125 \%$ PVA fibers

\section{EVALUATION OF SELF COMPACTING CONCRETE}

It is important to appreciate that none of the test methods for self compacting concrete has yet been standardized, and the tests described are not yet perfect or definitive. The methods followed in this investigation are explained in below sections. They are mainly ad-hoc methods, which have been derived specially for self compacting concrete.

\subsection{Tests on Fresh concrete:}

Self compacting concrete in plastic state exhibits three basic characters. Those are flow ability, passing ability and resistance towards segregation. Various tests are performed to check these properties of fresh self compacting concrete. Some of these tests are as follows:

1) Slump flow test

2) L-Box test

3) V-funnel test

\subsubsection{Slump flow test:}

In this test a square plate of $850 \mathrm{~mm}$ was used which is of smooth, water tight and rigid. Handles, if necessary shall be installed such that it does not disturb the slump flow measurement. Wipe the internal and external surfaces of slump cone and the plate with wet cloth which is laid horizontally now fill the cone with concrete up to the brim and wipe the excess concrete so that it produces a even surface on the top of the cone. Raise the cone slowly in a gradual manner and note the dimensions of the slump formed on the plate with a scale or measuring tape.

\subsubsection{L-Box test:}

The apparatus consists of a rectangular-section box in the shape of an ' $L$ ', with a vertical and horizontal section, separated by a moveable gate, in front of which vertical lengths of reinforcement bar are fitted. The vertical section is filled with concrete, and then the gate lifted to let the concrete flow into the horizontal section. When the flow has stopped, the height of the concrete at the end of the horizontal section is expressed as a proportion of that remaining in the vertical section $\left(\mathrm{H}_{2} / \mathrm{H}_{1}\right.$ in the diagram). It indicates the slope of the concrete when at rest. This is an indication passing ability, or the degree to which the passage of concrete through the bars is restricted.

\subsubsection{V-funnel test:}

In this test a funnel of $\mathrm{V}$-shape with a closing at the bottom was used in which concrete of required mix is poured into it up to the brim. Now remove the excess concrete using a spatula so, that it forms a smooth surface on the top of the funnel. Using a stop watch the time required by the funnel to empty the concrete is calculated by opening the valve of the funnel. 


\subsection{Tests on Hardened concrete:}

4.2.1 Compressive strength:

Compression test was conducted on $150 \mathrm{~mm} \times 150 \mathrm{~mm} \times 150 \mathrm{~mm}$ cubes. Concrete specimens were removed from curing tank and cleaned. In the testing machine, the cube is placed with the cast faces at right angles to that of compressive faces, then load is applied at a constant rate of $1.4 \mathrm{~kg} / \mathrm{cm}^{2} /$ minute up to failure and the ultimate load is noted. The load is increased until the specimen fails and the maximum load is recorded. The compression tests were carried out at 7, 28, 56 days. For strength computation, the average load of three specimens is considered for each mix. The average of three specimens was reported as the cube compressive of strength.

Cube compressive strength

$$
=\frac{\text { Load }}{\text { Area of cross section }}
$$

\subsubsection{Split tensile strength test:}

The cylinder specimen is of the size $150 \mathrm{~mm}$ diameters and $300 \mathrm{~mm}$ length. The test is carried out by placing a cylindrical specimen horizontally between the loading surfaces of compression testing machine and the load is applied until failure of cylinder, along its longitudinal direction. The cylinder specimens are tested at 7 days, 28 days and 56 days. The average of three specimens was reported as the split tensile strength.

$$
\begin{aligned}
& \text { Split tensile strength }=\frac{2 \times \mathrm{P}}{\pi \times \mathrm{D} \times \mathrm{L}} \\
& \text { Where } \begin{array}{l}
\mathrm{P}=\text { compressive load on the cylinder. } \\
\mathrm{L}=\text { length of the cylinder. } \\
\mathrm{D}=\text { diameter of the cylinder. }
\end{array}
\end{aligned}
$$

\subsubsection{Flexural Strength Test:}

In the flexural strength test theoretical maximum tensile stress reached at the bottom fibres of the test beam is known as the modulus of rupture. When concrete is subjected to bending stress, compressive as well as tensile stresses are developed at top and bottom fibres respectively. The strength shown by the concrete against bending is known as flexural strength. The standard size of specimen is $150 \mathrm{~mm} \times 150 \mathrm{~mm} \times 700 \mathrm{~mm}$.

The flexural strength of the specimen is expressed as the modulus of rupture ' $\mathbf{f}_{\mathbf{b}}$ ' which, if ' $\mathrm{a}$ ' equals the distance between the line of fracture and the nearest support measured on the centre line of the tensile side of the specimen, in $\mathrm{cm}$, is calculated to the nearest $0.05 \mathrm{Mpa}$ as follows.

$$
f_{b}=\frac{\mathrm{PL}}{\mathrm{bd}^{2}}
$$

When 'a' greater than $20 \mathrm{~cm}$ for $15 \mathrm{~cm}$ specimen

$$
f_{b}=\frac{a P a}{b d^{2}}
$$

when ' $\mathrm{a}$ ' is less than $20 \mathrm{~cm}$ but greater than $17 \mathrm{~cm}$ for $15 \mathrm{~cm}$ specimen or less than 13.30 But greater than $11.00 \mathrm{~cm}$ for a $10 \mathrm{~cm}$ specimen.

$$
\text { Where } \begin{aligned}
\mathrm{P} & =\text { ultimate load in } \mathrm{N} \\
\mathrm{L} & =\text { span of the beam in } \mathrm{mm} \\
\mathrm{b} & =\text { width of the specimen in } \mathrm{mm} \\
\mathrm{d} & =\text { depth of the specimen in } \mathrm{m}
\end{aligned}
$$

The flexural beam specimens are tested at 7 days, 28 days and 56 days. The average of three specimens was reported as the flexural tensile strength.

\subsubsection{Durability test methods:}

The durability of concrete is defined as its ability to resist weathering action, chemical attack, abrasion, or any other process of deterioration. Durable concrete will retain its original form, quality, and serviceability when exposed to environment.

\subsubsection{Sea water curing:}

On an average, seawater in the world's oceans has a salinity of approximately $3.5 \%$, or 35 parts per thousand. This means that for every 1 litre $(1000 \mathrm{ml})$ of seawater there are 35 grams of salts (mostly, but not entirely, sodium chloride) dissolved in it. Although a vast majority of seawater is found in oceans with salinity around $3.5 \%$, seawater is not uniformly saline throughout the world.

In this investigation the cubes were cast and cured in sea water for the age of 28 days. Average $\%$ decrease in weight and average $\%$ decrease in compressive strength were evaluated. 
The chemical composition of the Sea water is tabulated as below

\begin{tabular}{|l|l|l|}
\hline S. No & Composition & Concentration(mg/l) \\
\hline 1 & $\mathrm{P}_{\mathrm{H}}$ & 8.30 \\
\hline 2 & Chloride content & 19.34 \\
\hline 3 & Sulphate content & 2701 \\
\hline
\end{tabular}

4.2.5 Modulus of elasticity test (Stress- strain behaviour of concrete):

A typical relationship between stress and strain for normal strength concrete is discussed. After an initial linear portion lasting up to about $30-40 \%$ of the ultimate load, the curve becomes non-linear, with large strains being registered for small increments of stress. The non-linearity is primary a function of the coalescence of micro cracks at the paste-aggregate interface. The ultimate stress is reached when a large crack network is formed within the concrete, consisting of the coalesced micro cracks and the cracks in the cement paste matrix. The strain corresponding to ultimate stress is usually around 0.003 for normal strength concrete. The stress-strain behaviour in tension is similar to that in compression.

\section{RESULTS AND DISCUSSIONS}

In this chapter, the test results of specimens. Behaviour of concrete specimens in terms of compressive, split tensile and flexural strengths and also the workability and durability characteristics of SCC at their respective ages of curing were represented.

\subsection{Tests on Fresh concrete:}

Table 1: Workability values

\begin{tabular}{|l|l|l|l|l|}
\hline S. No & $\begin{array}{c}\text { Mix } \\
\text { notation }\end{array}$ & Slump flow(mm) & L-Box Ratio & V-funnel(sec) \\
\hline 1 & FA-0 & 659 & 0.8 & 12 \\
\hline 2 & FA-10 & 669 & 0.89 & 11 \\
\hline 3 & FA-20 & 695 & 0.91 & 10 \\
\hline 4 & FA-30 & 720 & 0.9 & 9 \\
\hline 5 & FA-40 & 750 & 0.93 & 9 \\
\hline
\end{tabular}

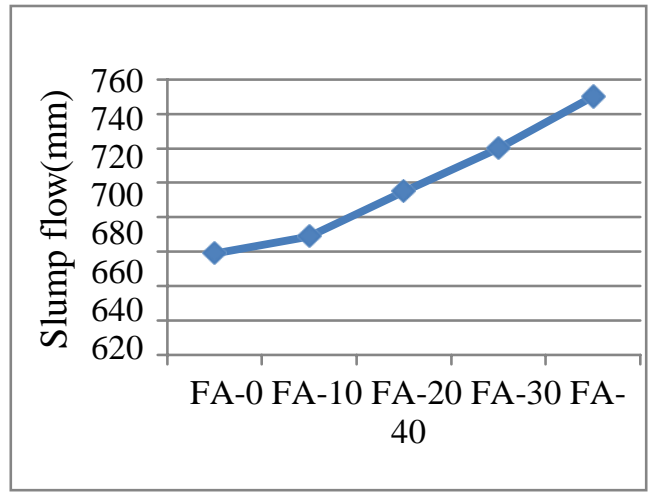

Comparison of slump flow

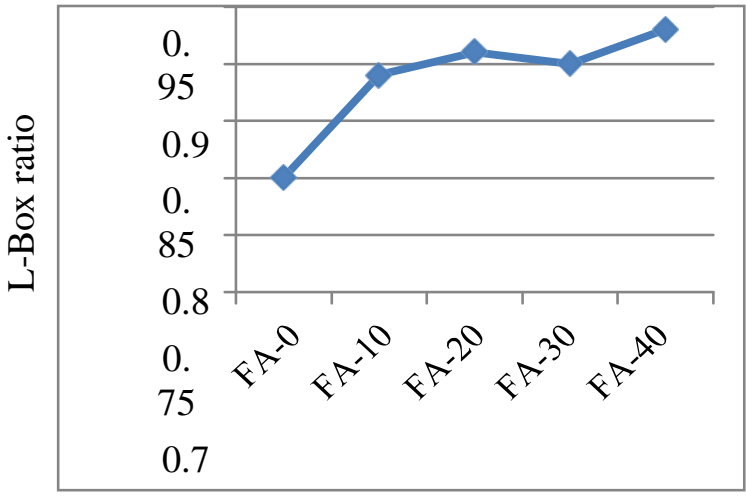

Comparison of L-Box ratio

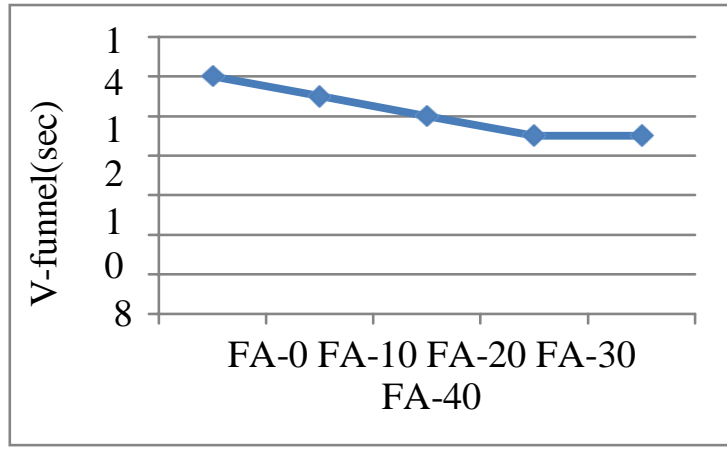

Comparison of V-funnel time

\subsection{Tests on Hardened concrete:}




\subsubsection{Compressive strength test:}

In this test cubes of standard size $150 \times 150 \times 150 \mathrm{~mm}^{3}$ were cast and the maximum load at failure was calculated using Compressive testing machine. The Compressive strength values are shown in the Table 2.

Table 2: Compressive strength values

\begin{tabular}{|l|l|l|l|}
\hline \multirow{2}{*}{$\begin{array}{c}\text { Mix } \\
\text { Notation }\end{array}$} & \multicolumn{3}{l|}{ Compressive strength(MPa) } \\
\cline { 2 - 4 } & $\mathbf{7}$ days & $\mathbf{2 8}$ days & $\mathbf{5 6}$ days \\
\hline FA-0 & 23.3 & 36.2 & 38.7 \\
\hline FA-10 & 24.1 & 38.1 & 40.2 \\
\hline FA-20 & 25.5 & 39.7 & 43.3 \\
\hline FA-30 & 26.2 & 42.1 & 45.1 \\
\hline FA-40 & 24.5 & 37.3 & 41.1 \\
\hline
\end{tabular}

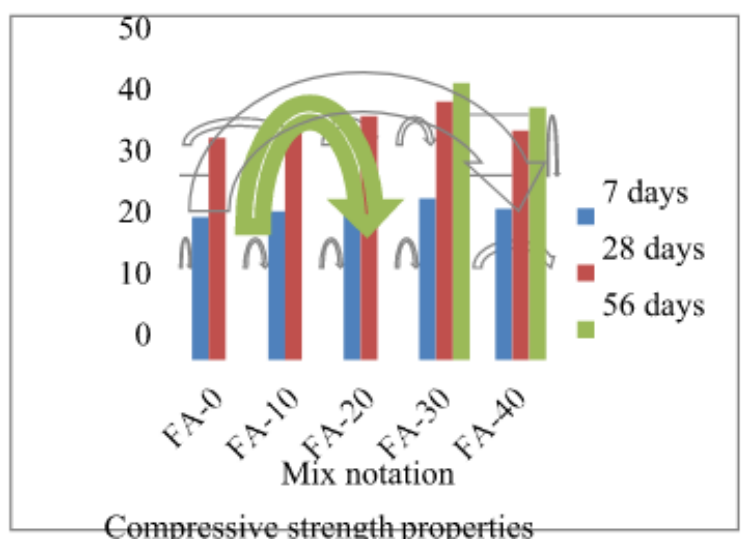

5.2.2 split tensile strength test:

In this test cylinders of standard dimensions of diameter $150 \mathrm{~mm}$ and height of $300 \mathrm{~mm}$ were cast and the maximum load at failure was calculated using Split tensile testing machine. The results were tabulated in table 3.

Table 3: split tensile strength values

\begin{tabular}{|l|l|l|l|}
\hline \multirow{2}{*}{$\begin{array}{c}\text { Mix } \\
\text { Notation }\end{array}$} & \multicolumn{3}{|l|}{ Split tensile strength (MPa) } \\
\cline { 2 - 4 } & $\mathbf{7}$ days & $\mathbf{2 8}$ days & $\mathbf{5 6}$ days \\
\hline FA-0 & 1.73 & 2.67 & 2.81 \\
\hline FA-10 & 1.8 & 2.74 & 2.85 \\
\hline FA-20 & 2.18 & 3.08 & 3.15 \\
\hline A-30 & 2.39 & 3.21 & 3.3 \\
\hline FA-40 & 1.87 & 2.98 & 3.1 \\
\hline
\end{tabular}

\subsubsection{Flexural strength:}

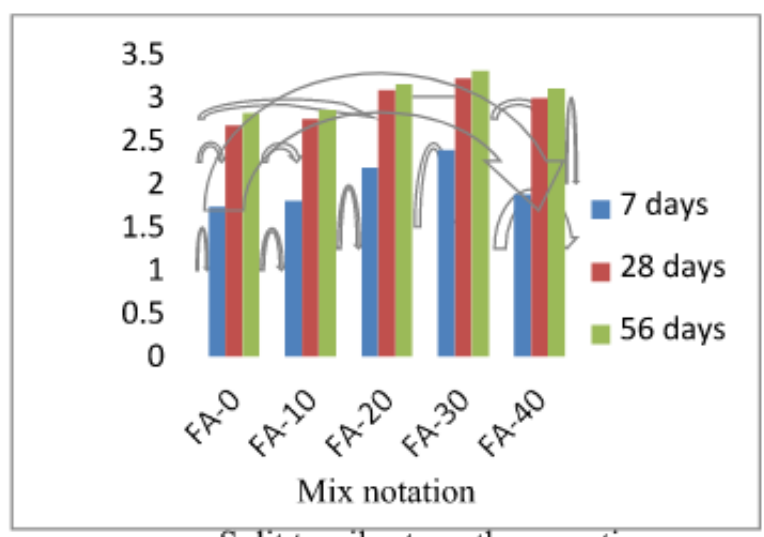

Split tensile strength properties

In this test prisms of standard dimensions $150 \times 150 \times 700 \mathrm{~mm}^{3}$ were cast and the maximum load at failure was calculated using flexural testing machine.

Table 4: Flexural strength values

\begin{tabular}{|l|l|l|l|}
\hline \multirow{3}{*}{$\begin{array}{c}\text { Mix } \\
\text { Notation }\end{array}$} & \multicolumn{3}{|l|}{ Flexural strength (MPa) } \\
\cline { 2 - 4 } & $\mathbf{7}$ days & $\mathbf{2 8}$ days & $\mathbf{5 6}$ days \\
\hline FA-0 & 3.6 & 4.3 & 5.6 \\
\hline FA-10 & 3.5 & 4.5 & 5.8 \\
\hline FA-20 & 4.2 & 5.3 & 6.1 \\
\hline FA-30 & 5.5 & 6.2 & 6.8 \\
\hline FA-40 & 4.8 & 5.1 & 5.4 \\
\hline
\end{tabular}

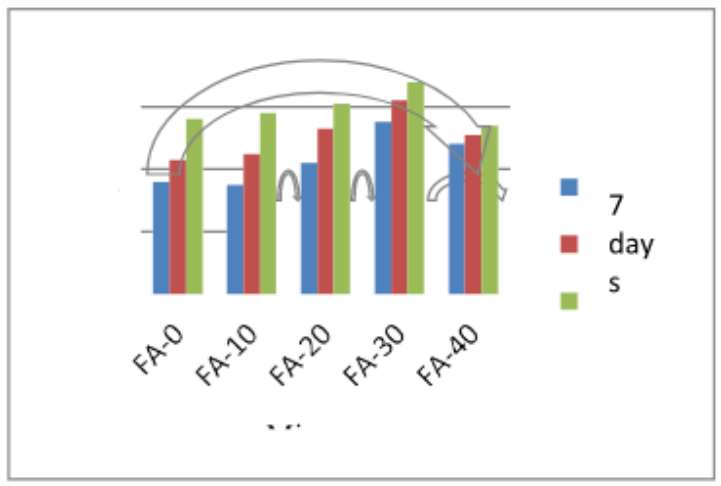

Flexural strength properties 
In the investigation cubes of standard size $150 \times 150 \times 150 \mathrm{~mm}^{3}$ were cast and cured in sea water for 28 days after 28 days of normal curing and the Weight and compressive strength is compared with cubes that are cured in normal water. Comparison of weight and Compressive strength comparison is tabulated in table 5.

Table 5: Durability test results

\begin{tabular}{|l|l|l|}
\hline Mix Notation & $\begin{array}{l}\text { age reduction in Weight } \\
(\mathbf{\%})\end{array}$ & $\begin{array}{c}\text { Average reduction in } \\
\text { compressive strength (\%) }\end{array}$ \\
\hline FA-0 & 1.5 & 7.9 \\
\hline FA-10 & 1.7 & 7.0 \\
\hline FA-20 & 1.4 & 6.4 \\
\hline FA-30 & 1.5 & 6.0 \\
\hline FA-40 & 1.8 & 5.9 \\
\hline
\end{tabular}
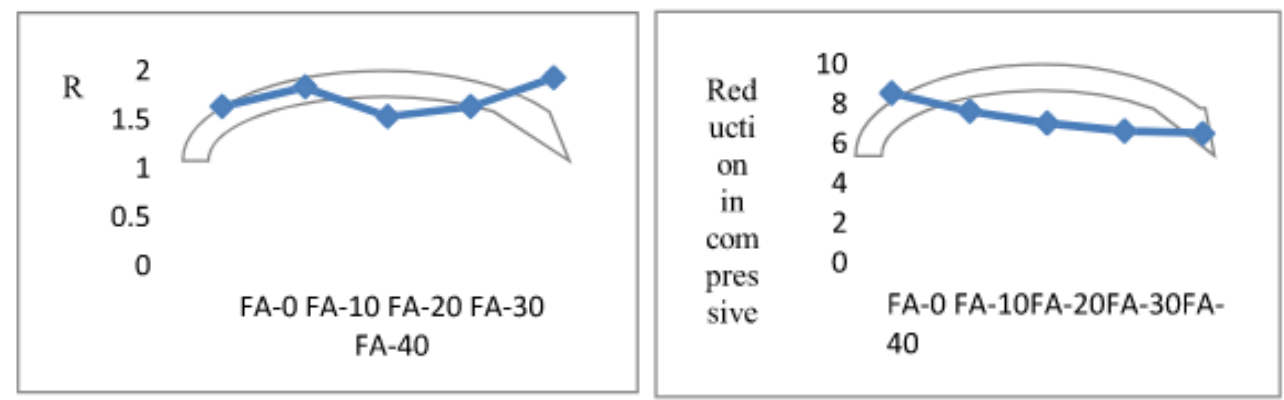

5.2.5 Stress-strain relationship (Modulus of Elasticity):

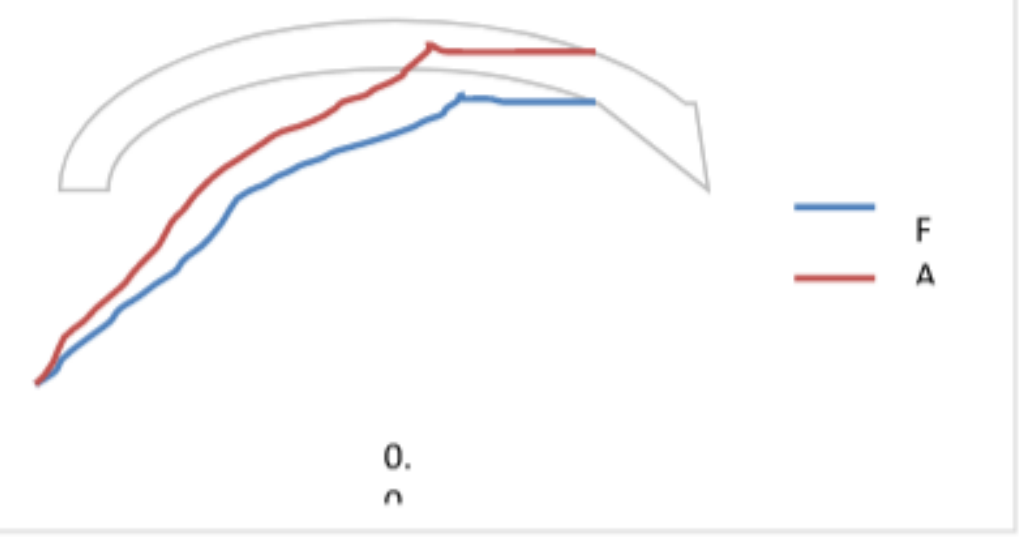

Ec-Theoretical $=5000 \sqrt{ } \mathrm{f}_{\mathrm{ck}}$

$=27386.13 \mathrm{~N} / \mathrm{mm}^{2}$

\begin{tabular}{|c|c|c|c|}
\hline \begin{tabular}{|l} 
Percentage \\
replacement $(\%)$
\end{tabular} & off $f_{\text {ck }}\left(N / \mathbf{m m}^{2}\right)$ & $\begin{array}{l}\text { heoretical }\left(\mathrm{N} / \mathrm{mm}^{2}\right) \\
5000 \sqrt{ } \text { Fck }\end{array}$ & $=$ Ec-practical $\left(\mathbf{N} / \mathbf{m m}^{2}\right)$ \\
\hline 0 & 30 & 27386.13 & 27793.86 \\
\hline 30 & 30 & 27386.13 & 22071.084 \\
\hline
\end{tabular}

\section{CONCLUSION}

- The workability properties are within the limits and increases with the increase in Fly Ash content up to $30 \%$ replacement.

- PVA fibers decrease the passing ability when the volume is more than $0.125 \%$.

- If Super plasticizer quantity is high segregation increases.

- Compressive strength increases up to $13-19 \%$ for 30\% Fly ash and $0.125 \%$ PVA fibers (by volume).

- Split tensile strength increases up to $20-38 \%$ for $30 \%$ Fly ash and $0.125 \%$ PVA fibers (by volume).

- Flexural strength increases up to $44-48 \%$ for $30 \%$ Fly ash and $0.125 \%$ PVA fibers(by volume). 
- For 28 days curing in Sea water, strength reduction and weight reduction is less when compared to Normal concrete.

- Stress-strain relation was observed and Modulus of Elasticity obtained is $27793.86 \mathrm{~N} / \mathrm{mm}^{2}$ for optimum.

\section{REFERENCES}

[1] Bertil person(2001) "A comparison between mechanical properties of self compacting concrete and the corresponding properties of normal concrete" cement and concrete Research 31, pp 193-198.

[2] Binu sukumar, k. Naga mani and R. Srinivasa Raghavan(2007) "Evaluation of strength at early ages of self compacting concrete with high volume of fly ash" Construction and building materials, pp 1-8.

[3] Cengiz Duran Aity(2005) "Strength properties of high -volume fly ash roller compacted and workable concrete and influence of curing condition" Cement and concrete research, 35: 1112-1121.

[4] Felekoglu, B.Turkel, S.Baradan(2006) " Effect of w/c ratio on the fresh and hardened properties of SCC" Building and Environmental Research vol:35;pp. 373-379.

[5] Girish, R.V.Ranganath and JagadishVengala(2010) “ Influence of powder and paste on flow properties of SCC:”Construction and Building mterials 24, Pp2481-2488.

[6] Graidc Zoran, Despotovic, Iva and Topliccuric, Gordana (2008) "Properties of self compacting concrete with different types of additives" Additives and civil Engineering . volume 6,no.2, pp 173-174.

[7] Khatib, J.M (2008) "Performance of self compacting concrete containing fly ash" Construction and Building materials, 22 : $1963-1971$.

[8] Paratibha aggrawal and Surinder M Gupta(2008) "Self compacting concrete-Procedure for mix deign" Leonardo Electronic journal of practices and Technologies, Issue 12, pp 15-24.

[9] Todorova E , Chemev G(2015) "Influence of chemical admixture on strength characteristics of self compacting concrete" Theoretical and applied Fracture Mechanics 78,pp 20-24.

[10] Zoran Gradic(2008) "Properties of self compacting concrete with different types of Admixtures"Construction and Building materials, 64, pp 586-598. 